\title{
Pandangan Dunia Tragis dalam Legenda Wadu Ntanda Rahi Suku Bima di Kota Bima Nusa Tenggara Barat
}

\author{
A Tragic Worldview in the Bima Tribe Legend "Wadu Ntanda Rahi" in Bima City \\ West Nusa Tenggara
}

\author{
Ari Wibowo ${ }^{1, *}$, Alfian Rokhmansyah ${ }^{2}$, dan Dahri Dahlan ${ }^{3}$ \\ ${ }^{1,2,3}$ Universitas Mulawarman \\ ${ }^{1}$ Corresponding email: arilakasipahu@gmail.com \\ ${ }^{2}$ Email: alfian.rokhmansyah@gmail.com \\ ${ }^{3}$ Email: dahridahlan@gmail.com
}

Received: 1 July 2021 Accepted: 31 July 2021 Published: 2 August 2021

\begin{abstract}
This study aims to describe the tragic worldview in the legend of Wadu Ntanda Rahi. This research is field research. The data of this research is the legend of Wadu Ntanda Rahi, the version of the people who live in the coastal part of Bima. The informants are the Bima Tribe, who was born, settled, and have lived in Bima City and know the legend of Wadu Ntanda Rahi. This study's data collection techniques were interviews and documentation using oral literature documentation forms, transcription, and translation. According to Goldmann, data analysis was carried out using a tragic world analysis model on the legend of Wadu Ntanda Rahi. The results show that in the legend of Wadu Ntanda Rahi, there is a tragic fate experienced by the two main characters in the story, namely La Nggusu (husband) and La Nggini (wife). La Nggusu suffered a tragic fate because he migrated who never returned to his hometown. La Nggusu's departure as a husband made La Nggini's life be lived alone. La Nggini often gets tragic things in her life. Her husband's departure was the beginning of La Nggini's tragedy, followed by the death of her closest family, which made her even more alone, until in the end, she hoped to become immortal, namely to become a stone. La Nggini's suffering is the result of the absence of God, the silent world, and the result of tragic human traits that demand the impossible.
\end{abstract}

Keywords: tragic worldview, Bima tribal legend, oral literature

\begin{abstract}
Abstrak: Tujuan penelitian ini adalah mendeskripsikan pandangan dunia tragis dalam legenda Wadu Ntanda Rahi. Penelitian ini merupakan penelitian lapangan. Data penelitian ini adalah legenda Wadu Ntanda Rahi versi masyarakat yang tinggal di Bima bagian pesisir, sedangkan informan penelitian adalah masyarakat Suku Bima yang lahir, menetap, dan pernah tinggal di Kota Bima, serta mengetahui cerita legenda Wadu Ntanda Rahi. Teknik pengumpulan data yang digunakan dalam penelitian ini adalah wawancara, dokumentasi dengan memanfaatkan formulir dokumentasi sastra lisan, transkripsi, dan penerjemahan. Analisis data dilakukan dengan model analisis dunia tragis menurut Goldmann pada legenda Wadu Ntanda Rahi. Hasil penelitian menunjukkan bahwa dalam legenda Wadu Ntanda Rahi terdapat nasib tragis yang dialami kedua tokoh utama dalam cerita, yaitu La Nggusu (suami) dan La Nggini (istri). La Nggusu mengalami nasib tragis karena merantau yang tidak pernah pulang ke daerah asal. Kepergian La Nggusu sebagai suami membuat kehidupan La Nggini dijalani dengan sendirian. La Nggini kerap mendapatkan hal-hal yang tragis dalam kehidupannya. Kepergian sang suami adalah awal dari ketragisan La Nggini, disusul dengan kematian keluarga terdekat yang membuat ia semakin sendiri, hingga pada akhirnya ia berharap menjadi abadi, yaitu menjadi batu. Penderitaan La Nggini tersebut adalah akibat dari ketidakhadiran Tuhan, dunia yang diam, serta akibat dari ciri-ciri manusia tragis yang menuntut hal-hal mustahil secara mutlak.
\end{abstract}

Kata kunci: pandangan dunia tragis, legenda suku Bima, sastra lisan

To cite this article:

Wibowo, A., Rokhmansyah, A., \& Dahlan, D. (2021). Pandangan Dunia Tragis dalam Legenda Wadu Ntanda Rahi Suku Bima di Kota Bima Nusa Tenggara Barat. Diglosia: Jurnal Kajian Bahasa, Sastra, dan Pengajarannya, 4(3), 335-350. https://doi.org/10.30872/diglosia.v4i3.283 


\section{A. PENDAHULUAN}

Legenda adalah cerita rakyat yang dianggap oleh yang empunya cerita sebagai suatu kejadian yang benar-benar pernah terjadi (Danandjaja, 2007, hal. 66). Legenda biasanya bersifat migratoris, yakni dapat berpindah-pindah sehingga dikenal luas di daerah yang berbeda-beda. Hal demikian menyebabkan adanya beberapa versi legenda yang tersebar di suatu daerah. Umumnya, suatu legenda dalam penyebarannya akan mengalami perubahan pada beberapa unsur, tetapi isi cerita masih dipertahankan. Watak tokoh, latar belakang tempat, serta alur cerita menjadi ciri khas tersendiri setiap legenda yang berada pada masyarakat kolektifnya.

Salah satu contoh legenda di nusantara yang memiliki dua versi adalah legenda Wadu Ntanda Rahi (selanjutnya disingkat WNR) milik Suku Bima. Legenda ini juga telah bertransformasi menjadi sebuah novel Wadu Ntanda Rahi karya Alan Malingi yang terbit tahun 2007 (Hasanah, 2018; Nurlaila, 2018). Novel ini mengambil 'bahan' legenda WNR sebagai 'bahan dasar' cerita dalam novel tersebut. Novel ini menggambarkan kehidupan Budaya masyarakat Bima (Mbojo) dalam kaitanya dengan perkawinan dan hidup bersosial dengan masyarakat sekitarnya. Yang mana di masyarakat Bima (Mbojo) dikenal dengan istilah karawi kaboju (Gotong royong) hal ini sudah menjadi kebiasaan di tengah-tengah masyarakat Bima (Mbojo). Novel ini cukup kuat menggambarkan kondisi tanah Bima saat itu, termasuk Budaya Bima tentang adat perkawinan pada masa itu dan di samping itu pula penulis ingin memperkenalkan adat perkawinan masyarakat Bima yang mulai terlupakan oleh perkembangan zaman.

Legenda $W N R$ memiliki dua versi, yaitu versi menurut masyarakat yang tinggal di daerah pesisir dan versi menurut masyarakat yang tinggal di daerah gunung. Menurut versi masyarakat yang tinggal di daerah pesisir, legenda $W N R$ diceritakan dengan tokohnya yang sering beraktivitas di pesisir misalnya, menjadi nelayan, membuat garam dan mencari tumbuhan laut. Sedangkan menurut masyarakat yang tinggal di daerah gunung, legenda $W N R$ diceritakan dengan tokohnya yang dominan beraktivitas di daerah gunung misalnya, berladang, mencari kayu bakar, dan berburu.

Perbedaan versi yang tersebut di atas tidak memengaruhi inti dari cerita legenda WNR, yaitu menceritakan kebiasaan lelaki suku Bima di Provinsi Nusa Tenggara Barat yang suka merantau. Tujuan dari lelaki suku Bima pergi merantau adalah mencari ilmu serta mencari pekerjaan yang penghasilannya lebih tinggi dari sekadar menjadi petani atau nelayan. Alasan lain lelaki suku Bima pergi merantau adalah pengaruh letak geografis pemukiman masyarakat suku Bima yang berada di Pulau Sumbawa. Pulau Sumbawa yang akses ke luar pulau dengan menggunakan jalur pesisir ini memiliki pelabuhan yang cukup banyak. Pulau Sumbawa merupakan daerah yang strategis karena pedagang dari Jawa yang menuju Sulawesi dan Nusa Tenggara Timur umumnya akan singgah di beberapa pelabuhan, di Pulau Sumbawa, salah satunya pelabuhan Bima. Banyaknya kapal yang berlabuh dan akan berlayar ke pulau seberang memudahkan lelaki Suku Bima untuk merantau. Menurut tokoh masyarakat Bima, tidak ada ketetapan waktu lelaki Suku Bima berangkat maupun pulang merantau. Lelaki yang masih bujang ataupun sudah beristri akan merantau apabila hal tersebut perlu untuk dilakukan. Di lain pihak, kaum perempuan yang ditinggalkan oleh keluarga maupun suaminya hanya akan terus menunggu sampai orang yang ditunggu pulang. Di masa penantian tersebut, kaum perempuan biasanya 
melakukan aktivitas berupa menenun dan berladang. Keadaan kaum perempuan demikian tergambar dalam cerita legenda $W N R$.

Dalam cerita legenda $W N R$, bukit Bedi dijadikan sebagai tempat penantian untuk menunggu kepulangan suami yang merantau oleh tokoh istri. Di Bukit Bedi terdapat sebuah batu besar yang menghadap ke utara. Bentuknya mirip tubuh manusia yang sedang memandang ke selat Bima. Masyarakat Suku Bima percaya bahwa bongkahan batu tersebut adalah wujud dari tokoh istri dalam legenda WNR yang telah menjadi batu. Selain di Kota Bima, masyarakat juga meyakini batu serupa juga terdapat di Kabupaten Bima yaitu: di Kecamatan Langgudu, Kecamatan Lambu, Kecamatan Wera, dan Kecamatan Belo. Di Kecamatan Belo ditemukan bongkahan batu yang menyerupai perkakas rumah tangga seperti alat dapur dan alat bertani.

Dalam penelitian ini yang menjadi objek penelitian adalah legenda $W N R$ versi masyarakat di tengah Kota Bima, yaitu di Kecamatan Mpunda. Kecamatan Mpunda termasuk daerah yang masyarakatnya bermukim di sekitar daerah pesisir pantai. Menurut tokoh masyarakat setempat, adanya situs sejarah berupa bongkahan batu yang berbentuk tubuh manusia di Bukit Bedi, Kecamatan Mpunda, menjadi bukti bahwa legenda tersebut benar-benar pernah terjadi pada masa lampau.

Legenda WNR menurut masyarakat yang bermukim di sekitar Bukit Bedi menceritakan seorang istri menunggu suaminya yang telah pergi merantau selama bertahun-tahun. Sang istri melewati segala rintangan sendirian, namun tidak meruntuhkan kesetiaan terhadap sang suami. Setiap ada kapal yang berlabuh, sang istri akan turun menuju pelabuhan untuk menanyakan kabar suaminya dari para penumpang. Ia akan naik jika tidak mendapati suaminya. Setelah sekian lama menunggu, sang istri mendapat kabar bahwa kapal yang ditumpangi suaminya telah karang di tengah pesisir. Akhirnya di atas bukit-di tengah masa penantiannyatokoh istri berubah menjadi batu.

Selain situs sejarah berupa bongkahan batu berbentuk tubuh manusia yang terdapat di beberapa tempat di daerah Suku Bima, sebuah lagu yang berjudul "Wadu Ntanda Rahi" diciptakan masyarakat Bima untuk mengabadikan dan mengungkapkan ketragisan yang dialami tokoh istri. Salah satu bagian liriknya yang berbunyi "Auku ncara ra kancaruna sampa ndadi kaina wadu?" (Apakah kesalahannya sehingga ia menjadi batu?) merupakan pertanyaan umum bagi Suku Bima masa sekarang karena masyarakat umumnya percaya bahwa sikap dan perbuatan baik dalam diri seseorang akan mendatangkan hal yang baik pula di masa mendatang. Namun, nasib tokoh istri yang tragis berbanding terbalik dengan kepercayaan masyarakat. Tokoh istri yang memiliki sifat setia pada akhirnya merasa kecewa karena tidak bisa bertemu sang suami. Kekecewaan tersebut menyebabkan ia memilih hidup menyendiri di bukit hingga Ia diyakini oleh masyarakat Bima telah menjadi batu. Adanya nasib tragis tersebut menyebabkan konsep pandangan dunia tragis Goldmann dianggap relevan. Pandangan dunia tragis dipahami sebagai dunia yang kontradiktif antara harapan dan kenyataan yang terjadi. Pendekatan dunia tragis akan digunakan untuk mengungkapkan tragedi yang terdapat pada legenda $W N R$. Pandangan dunia tragis memiliki tiga elemen yang semuanya saling berhubungan yaitu, pandangan mengenai Tuhan, pandangan mengenai dunia, dan pandangan mengenai manusia (Faruk, 2012, hal. 82).

Berdasarkan uraian di atas, penelitian ini bertujuan untuk mendeskripsikan pandangan dunia tragis yang terdapat dalam legenda Wadu Ntanda Rahi yang 
dimiliki oleh masyarakat suku Bima di Nusa Tenggara Barat. Konsep pandangan dunia tragis yang dimanfaatkan dalam penelitian ini mengacu pada konsep Goldmann sebagaimana yang telah dipaparkan sebelumnya. Dalam buku The Hidden God, Goldmann (2013) memaparkan konsep mengenai konsep pandangan dunia tragis yang merupakan pandangan dunia yang diekspresikan oleh karya-karya sebagai objeknya (Faruk, 2012, hal. 81).

Secara mendasar pandangan dunia menurut Goldmann $(1977,1980)$ adalah gagasan-gagasan, aspirasi-aspirasi, dan perasaan-perasaan yang kompleks dan menyeluruh, yang menghubungkan secara bersama-sama anggota-anggota suatu kelompok sosial tertentu yang mempertentangkannya dengan kelompok-kelompok sosial yang lain (Faruk, 2012, hal. 65-66). Dengan demikian, pandangan dunia tidak hanya seperangkat gagasan abstrak dari suatu kelas mengenai kehidupan manusia dan dunia tempat manusia itu berada, melainkan juga merupakan semacam cara atau gaya hidup yang dapat mempersatukan anggota satu kelas dengan anggota yang lain dalam kelas yang sama dan membedakannya dari anggota-anggota kelas sosial yang lain. Goldmann juga mengatakan bahwa sejak akhir zaman dahulu sampai saat ini, kelas sosial merupakan infrastruktur pandangan dunia (Cohen, 1994, hal. 151). Goldmann menempatkan karya sastra dan filsafat sebagai fenomena yang kompleks dan berhubungan dengan ide-ide abstrak masyarakatnya dan terkait dengan pandangan dunia atau visi dunia pengarang. Selanjutnya, Goldmann menunjukkan karya sastra dan filsafat dapat menjelaskan basis sosial atau suatu masyarakat (Anwar, 2012, hal. 120).

Menurut Goldmann (2013, hal. 33) pandangan dunia tragis adalah kebertentangan dua hal, yaitu pemahaman akan dunia adalah segalanya dan penolakan bahwa dunia tersebut sebagai satu-satunya tempat manusia hidup dan bereksistensi. Pandangan dunia tragis merupakan suatu ruang yang paradoksal dan dualisme. Menurut Goldmann, pandangan dunia tragis mengandung tiga elemen, yaitu pandangan mengenai Tuhan (the tragic vision: god), pandangan mengenai dunia (the tragic vision: world), dan pandangan mengenai manusia (the tragic vision: man) (Ramadhani, Rokhmansyah, \& Dahlan, 2020). Pandangan mengenai Tuhan, yaitu manusia menyadari kehadiran Tuhan yang tidak melepaskan tuntutan-Nya atas perilaku kehidupan. Konsep mengenai Tuhan yang paradoksal demikian disebut Goldmann (2013, hal. 36) sebagai Tuhan yang bersembunyi (The Hidden God). Menurut Goldmann (2013, hal. 38) pandangan mengenai Tuhan tragis (the tragic vision: God) sangat terkait dengan pandangan rasionalisme tentang Tuhan. Tuhan bagi kaum rasionalis terepresentasikan dalam jiwa manusia, eksistensi Tuhan hadir untuk menjamin adanya kebenaran abadi.

Selanjutnya menurut Goldmann (2013, hal. 52), pandangan mengenai dunia (the tragic vision: world) adalah segala sesuatu yang mungkin menurut hukum duniawi menjadi tidak ada dan tidak berarti di hadapan Tuhan. Goldmann (2013, hal. 49) mengatakan bahwa segala sesuatu tuntutan Tuhan di mata dunia adalah mustahil. Tetapi sebaliknya, segala tuntutan mengenai hukum dunia tidaklah berarti di mata Tuhan. Manusia mengetahui keterbatasan dunia dan karena itu menolaknya. Akan tetapi, pemahamannya akan nilai ketuhanan, hanya bisa diperoleh dalam dunia itu sendiri. Manusia menolak segala keterbatasan keduniawian, tetapi kepercayaan mengenai Tuhan tetap ketat didapatkan dari dalam dunia itu.

Panda konsep pandangan mengenai manusia (the tragic vision: man), Goldmann menjelaskan dalam elemen pandangan dunia tragis bahwa manusia tragis memiliki 
dua ciri. Menurut Goldmann (2013, hal. 62), ada dua karakteristik penting dari manusia tragis yang harus dicatat jika kita melihatnya sebagai realitas manusia yang koheren: pertama adalah bahwa ia membuat permintaan mutlak dan eksklusif ini untuk nilai-nilai yang mustahil; dan kedua adalah bahwa, sebagai akibat dari ini, permintaannya adalah untuk 'semua atau tidak sama sekali', dan dia sama sekali tidak peduli dengan derajat dan perkiraan, dan konsep apa pun yang mengandung ide relativitas. Dengan sikap paradoksal tersebut, manusia sekaligus raja dan budak, iblis dan malaikat (Goldmann, 2013, hal. 63). Dalam posisi tersebut manusia tragis berada di dua keadaan pandangan mengenai Tuhan, yaitu Tuhan tidak hadir bila dipandang dari nasib dan kemalangan yang dialami manusia, tetapi Tuhan hadir ketika dilihat dari sudut kebesarannya-Nya, dan atas tuntutan manusia berserta kebenaran dan keadilan yang diciptakan.

Bagi Goldmann (2013, hal. 62), elemen tragis mengenai Tuhan, dunia, dan manusia tidak paradoksal dalam dirinya sendiri. Tuhan sebagai Tuhan tidak pernah ambigu dan paradoks, demikian halnya manusia sebagai manusia dalam dirinya juga tidak ada masalah, dunia dalam dirinya juga tidak mengalami masalah tragis. Pertemuan antara Tuhan, dunia, dan manusia dalam sebuah ruang dan waktu yang sama itulah yang menimbulkan visi tragis dan tragedi.

\section{B. METODE}

Penelitian ini merupakan penelitian lapangan karena meneliti sastra lisan yang masih hidup di kolektifnya. Penelitian lapangan dalam lingkup sastra lisan adalah penelitian yang secara langsung dan eksklusif meneliti suatu gejala di masyarakat mengenai persoalan seputar kesusastraannya dan memunyai peran penting dalam kehidupan masyarakat sehingga pengumpulan data harus secara cermat menangkap maksud pencerita dalam menuturkan sastra lisan. Data dalam penelitian ini adalah legenda Wadu Ntanda Rahi versi masyarakat suku Bima yang tinggal di daerah pesisir. Sedangkan sumber data adalah informan yang memiliki ciri-ciri, yaitu masyarakat Suku Bima yang lahir, menetap, atau pernah tinggal di Kota Bima yang mengetahui cerita legenda tersebut. Langkah pertama yang dilakukan dalam pengumpulan data penelitian ini adalah penentuan informan sebagai sumber data. Penentuan informan harus cermat agar data yang didapatkan berkualitas dan relevan dengan penelitian sehingga data dari penuturan informan dapat menjadi perwakilan keseluruhan inti cerita yang ketahui oleh masyarakat kolektifnya.

Teknik pengumpulan data penelitian ini, antara lain wawancara, dokumentasi, transkripsi, dan penerjemahan. Teknik wawancara digunakan untuk merekam data tradisi (lisan) masyarakat Tengger yang tidak dapat direkam melalui pengamatan (Hasanah \& Sukmawan, 2021; Sudikan, 2001, hal. 87). Selanjutnya dokumentasi sastra lisan dengan memanfaatkan formulir dokumentasi sastra lisan (Danandjaja, 2007). Transkripsi dilakukan untuk pengalihan data lisan ke dalam bentuk tulisan, yang dilanjutkan dengan penerjemahan bahasa Bima ke bahasa Indonesia pada data yang telah ditranskripsi. Proses analisis penelitian ini dilakukan dengan model alir (Miles, Huberman, \& Saldana, 2018), yaitu pengumpulan data, reduksi data, penyajian data, dan penarikan simpulan. Teknik analisis data memanfaatkan model analisis Goldmann khususnya pada pengungkapan pandangan dunia tragis. 


\section{PEMBAHASAN}

Dalam penelitian ini terdapat tiga langkah yang dilakukan untuk mendapatkan data berupa teks, yaitu transkripsi, terjemahan secara harfiah ke dalam Bahasa Indonesia, dan terjemahan sesuai pedoman Bahasa Indonesia yang baku. Dalam langkah pertama, transkripsi data diterapkan pada data lisan dari tiga narasumber sehingga data teks awal dapat diproses pada langkah selanjutnya. Hasil transkripsi dan hasil penerjemahan ketiga teks legenda Wadu Ntanda Rahi dari setiap narasumber digabungkan. Adapun penggabungan teks tersebut bertujuan untuk mendapatkan data yang dianggap memiliki kualitas baik karena berasal dari beberapa narasumber. Dalam tahap penggabungan, terdapat cara kerja berupa mengeliminasi narasi-narasi cerita yang sama dari setiap narasumber. Adapun cara kerja lain berupa penambahan narasi untuk melengkapi bagian teks yang dianggap kurang dalam alur jalannya cerita. Penambahan narasi demikian berpedoman pada tradisi dan budaya Suku Bima yang mendukung alur cerita Wadu Ntanda Rahi.

Adapun teks legenda Wadu Ntanda Rahi hasil transkripsi, terjemahan secara harfiah ke dalam Bahasa Indonesia, dan terjemahan sesuai pedoman Bahasa Indonesia dari ketiga narasumber adalah sebagai berikut.

\section{Wadu Ntanda Rahi}

Dulu, di tepi Teluk Bima hiduplah sekelompok masyarakat yang di dalamnya terdapat tokoh bernama La Nggini dan La Nggusu. Kedua muda mudi itu dipertemukan dalam sebuah kegiatan panen raya masyarakat pada saat itu. Mereka saling jatuh cinta dan pada akhirnya mereka sepakat untuk menikah. Mereka menikah sesuai adat dan istiadat yang berlaku di masyarakat, yaitu masyarakat Suku Bima. Mereka berdua adalah anggota masyarakat yang taat terhadap adat.

Setelah menikah, La Nggusu, Sang Suami, memiliki keinginan untuk pergi merantau. Ia ingin mencari pekerjaan di daerah yang memiliki penghasilan tinggi. Keinginan tersebut awalnya ditentang oleh orang tua dan istrinya, $\mathrm{La}$ Nggini. Tetapi setelah berunding, mereka pun sepakat terhadap keinginan La Nggusu. Akhirnya la Nggusu akan pergi merantau. Sebelum pergi, mereka berdua mengikrar sumpah agar selalu setia meskipun keberadaan keduanya sedang dalam jarak yang jauh. "Aku pergi dengan hati gundah, kamu di sini dengan kerinduanmu" kata Sang Suami. Kemudian sang istri menjawab "Kamu pergi dengan kegundahanmu wahai suamiku, aku di sini dengan kerinduanku".

Akhirnya sang suami pergi. Di sisi lain, La Nggini mendaki bukit dengan membawa sebuah peti yang dijadikan tempat berdiri untuk memandang ke arah laut. Setelah beberapa lama kepergiannya, sang suami tidak pernah memberikan kabar kepada sang Istri, La Nggini. La Nggini pun merasakan penderitannya sendirian. Penderitaan itu dimulai dari kematian pamannya, kemudian disusul oleh kematian kedua mertuanya, dan puncaaknya adalah ketika La Nggini difinah oleh temannya sendiri. La Nggini difitnah telah bermain dengan lelaki lain, padahal ia masih berstatus sebagai istri La Nggusu. Dalam adat Suku Bima, selingkuh adalah perbuatan paling tidak baik, hukumannya adalah kedua pihak yang selingkuh diarak keliling kampung.

Karena banyak mengalami penderitaan, akhirnya La Nggini mulai mendaki bukit di dekat perkampungan itu. Ia mulai akrab dengan bukit itu hingga ia membawa kembali sebuah peti berisi perlengkapan hidup di atas bukit. 
Setiap ditimpa masalah, La Nggini akan mendaki bukit, termasuk ketika pada saat semua orang terdekatnya telah meninggal.

Ketika ia benar-benar mulai merasakan penderitaan, La Nggini mendaki bukit kemudian mengabarkan kepada sang suami bahwa ia telah hidup sebatang kara. Begitu pun ketika Langgini difitnah, ia naik ke bukit untuk menyampaikan keluh kesahnya kepada La Nggusu melalui angin.

Ternyata La Nggusu pun merasakan apa yang dialami oleh La Nggini. Ia merasakan penderitaan yang dialami oleh La Nggini yang disampaikan angin kepadanya. Tetapi di sisi lain, La Nggusu pun mengalami masalahnya sendiri, ia digoda oleh seseorang yang berada di tempat ia merantau. La Nggusu ingin dijodohkan dengan anak mandornya yang kaya raya. Begitupun La Nggini, digoda oleh nakhoda yang kaya rasa.

Dalam keadaan demikian, La Nggini ingin menyerah dengan pendiriannya dan mengingkar janjinya yang pernah dikrarkan bersama sang suami. Tetapi ia menguatkan diri dengan terus mendaki bukit dan menghindari kehidupan di perkampungan yang tidak tenteram untuknya.

Di sisi lain, akhirnya La Nggusu memutuskan untuk kembali pada istrinya, ia memutuskan pulang dari perantauannya. Tetapi di tengah perjalanan pulangnya, kapal yang ditumpangi La Nggusu diterjang badai yang amat besar dan akhirnya tenggelam.

Kabar tentang kepulangan La Nggusu sudah didengar oleh La Nggini. Ia masih berada di atas bukit dan tidak mau turun sebelum benar memastikan kebenaran kabar kepulangan sang Suami. Ia menggunakan peti milikinya sebagai tempat ia berdiri untuk memandang ke arah laut, ia ingin melihat kapal yang ditumpangi sang suami. Akhirnya kabar itu benar-benar sampai dan La Nggini memutuskan untuk turun dari bukit dan menunggu sang Suami yang dalam tengah perjalanan pulang. Ia menunggu dan menunggu di dermaga.

Tetapi harapan dari La Nggini ternyata sia-sia. Kapal yang dinanti-nanti telah karam di tengah lautan. Kabar duka itu disampaikan oleh korban yang selamat. Mereka mengatakan bahwa kapal tersebut karam dan La Nggusu tidak terselamatkan. Lalu tiba-tiba seekor burung terbang di udara menjatuhkan selembar sapu tangan kuning yang sempat La Nggini berikan kepada La Nggusu ketika akan pergi merantau. Akhirnya dengan kembalinya sapu tangan kuning itu, La Nggini memperkuat seluruh keyakinannya bahwa sang suami telah meninggal. Sapu tangan itu diambil kemudian ia lari hingga ke bukit yang sudah menjadi teman peraduannya. La Nggini meminta kepada Tuhan agar cintanya diabadikan. Ia menginginkan kisah cintanya yang penuh kesetiaan dapat disaksikan oleh generasi yang akan mendatang. Hari itu tiba-tiba menjadi gelap, cuaca mulai dingin. Petir dan guntur mendera di langit. La Nggini tetap berdiri di atas peti, ia memandang ke arah laut hingga ia menjadi batu.

Secara keseluruhan alur cerita legenda Wadu Ntanda Rahi merupakan suatu cerita yang tragis. Tokoh yang paling menonjol ketragisannya adalah La Nggini, yaitu seorang istri yang menunggu kepulangan suaminya. Dalam waktu penantiannya, La Nggini kerap mengalami permasalahan dan penderitaan, hingga di akhir cerita penantiannya sia-sia karena sang suami meninggal di tengah perjalanan pulang. Selain La Nggini, tokoh La Nggusu pun mengalami ketragisan, yaitu ketika ia hendak pulang dari perantauan, kapal yang ditumpanginya karam di tengah perjalanan pulang, hingga ia tidak pernah sampai kepada La Nggini. 
Hal di atas sangat berkaitan dengan pandangan dunia tragis yang dikemukakan oleh Goldmann. Secara sederhana, Goldmann mengatakan bahwa pandangan dunia tragis adalah pertentangan dua hal dalam kurun waktu dan ruang yang sama, kedua hal tersebut terjadi dan paradoksal. Pandangan dunia tragis memiliki tiga elemen, yaitu pandangan mengenai Tuhan, pandangan mengenai dunia, dan pandangan mengenai manusia. Berikut analisa teks legenda Wadu Ntanda Rahi dengan menggunakan tiga elemen pandangan manusia tragis.

\section{Pandangan Mengenai Tuhan}

Melalui The Hidden God, Goldmann melihat ketiadaan peran Tuhan dalam kehidupan manusia sehingga disebut Tuhan tidak hadir, akan tetapi Tuhan itu ada dalam pikiran manusia dan tidak melepaskan tuntutan atas segala perilaku kehidupan manusia. Goldman menyebutkan kedua kondisi tersebut sebagai Tuhan yang bersembunyi. Tuhan ada ketika manusia memiliki harapan, tetapi Tuhan absen ketika harapan tersebut tidak menjadi kenyataan (Goldmann, 2013, hal. 36). Dalam legenda Wadu Ntanda Rahi, terdapat beberapa peristiwa yang relevan dengan dua keadaan yang kontradiktif dalam konsep Tuhan tragis. Dalam legenda Wadu Ntanda $R a h i$, dapat dilihat bahwa hubungan manusia dengan Tuhan dalam kenyataan terjadi tidak sesuai dengan apa yang diharapkan. Selain itu, ketidakberperanan Tuhan sebagai wasit atau hakim untuk mencegah ketidakadilan menguatkan prasangka ketiadaan-Nya. Tetapi, muncul juga prasangka bahwa apa yang terjadi dalam kehidupan adalah harapan yang terkabul karena kehendak dari Tuhan (Frederico, 2012; Ramadhani et al., 2020). Dalam tahap analisis ini, kedua kontradiksi tersebut dibagi menjadi dua keadaan yang kausalitas, yaitu Tuhan ada dan Tuhan tidak ada seperti dalam tabel di bawah ini.

Tabel 1. Perbandingan Keberadaan Tuhan

\begin{tabular}{cll}
\hline No & Tuhan Hadir & Tuhan Tidak Hadir \\
\hline 1 & Menikah & Berpisah \\
2 & Pulang & Tidak sampai tujuan \\
3 & Berharap bertemu & Tidak bertemu \\
\hline
\end{tabular}

Keadaan Tuhan tragis sangat jelas digambarkan dalam permulaan cerita legenda Wadu Ntanda Rahi, yaitu pernikahan yang berujung perpisahan. Dalam legenda Wadu Ntanda Rahi kedua tokoh utama pada awalnya menjalani kehidupan masing-masing. Ketika masa panen raya tiba, para penduduk berserta kedua tokoh utama mengikuti rangkaian kegiatan tradisi yang biasa dilaksanakan oleh masyarakat Suku Bima tersebut. Dari kegiatan tersebut kedua tokoh utama bertemu dan saling menyukai. Hingga pada suatu hari kedua tokoh utama tersebut memutuskan untuk menikah (Tuhan hadir). Tidak lama setelah menikah tokoh suami memiliki keinginan untuk merantau sehingga tokoh istri menjalani kehidupan sendiri atau berpisah dari tokoh suami (berpisah) (Tuhan tidak hadir).

Sebagai makhluk sosial, manusia pada dasarnya tidak mampu menjalani kehidupannya sendirian. Sejak dilahirkan secara sadar atau tidak sadar manusia sudah menjalani kehidupan berkelompok. Ketika masih bayi, manusia secara tidak sadar telah menjalin hubungan sosial dengan orang tua, sedangkan orang tua secara sadar dan bertanggung jawab merawat anak yang telah dilahirkan. Ketika dalam 
perkembangan menuju remaja, manusia menginginkan manusia lain sebagai teman yang memiliki kesamaan dalam hal pergaulan. Pada tahap remaja menuju dewasa, manusia normal secara natural dan sosial menginginkan manusia lain sebagai teman hidup. Pada tahap terakhir tersebut manusia menjalani kehidupan dengan manusia lain secara sah berdasarkan hukum dan agama (menikah).

Dalam legenda Wadu Ntanda Rahi, tokoh La Nggini dan La Nggusu melakukan pernikahan. Pada dasarnya pernikahan adalah harapan yang dimiliki oleh manusia. Harapan tersebut adalah harapan untuk hidup bersama dalam kebahagiaan. Menurut Undang-Undang Nomor 1 Tahun 1974 tentang Perkawinan, definisi perkawinan atau pernikahan adalah ikatan lahir batin antara seorang pria dengan seorang wanita sebagai suami istri dengan tujuan membentuk rumah tangga yang bahagia lahir maupun batin dan kekal berdasarkan ketuhanan Yang Maha Esa. ${ }^{1}$

Menurut Goldman Tuhan hadir ketika manusia memiliki harapan. Harapan akan pernikahan yang diinginkan oleh kedua tokoh utama dalam legenda Wadu Ntanda Rahi pada akhirnya menjadi kenyataan. Tetapi tidak lama setelah menikah tokoh suami memiliki keinginan untuk merantau. Pada akhirnya tokoh suami pergi merantau dan meninggalkan tokoh istri menjalani kehidupan sendirian atau hidup berpisah dengan tokoh suami.

Dalam kesendiriannya tokoh istri mengalami penderitaan. Harapan akan kehidupan bahagia setelah menikah tidak dirasakan oleh tokoh istri. Menurut Goldmann Tuhan tidak hadir ketika harapan tidak sesuai kenyataan. Tokoh istri menjalani kehidupan sendirian tanpa kehadiran suami. Tokoh istri berharap kehidupan yang bahagia setelah menikah, namun harapan itu sia-sia. Goldmann menyebutkan harapan yang sia-sia itu sebagai kekalahan manusia akibat Tuhan tidak hadir dalam kehidupannya. Dalam ketidakhadirannya Tuhan tetap memberi peraturan dan perintah-perintah yang mesti dijalani oleh manusia. Hal demikian dirasakan oleh tokoh istri, La Nggini. La Nggini tidak bisa melakukan hal apa pun selain menjalani penderitaan sendiri karena ditinggal oleh La Nggusu, tokoh suami. La Nggini tidak memiliki keinginan mencari teman hidup lain. Selain karena cinta terhadap La Nggusu, La Nggini tidak bisa mencari teman hidup lain untuk menolong derita yang dialaminya karena norma dan adat yang berlaku di masyarakat. Menikah atau mencari pasangan hidup yang lain harus dalam keadaan sedang tidak terikat secara hukum dan agama (menikah) dengan anggota masyarakat lain.

Di sisi lain, tokoh suami mengalami nasib tragisnya sendiri. Dalam perantauannya La Nggusu menahan diri untuk tidak menuruti keinginan mandor yang menjodohkannya karena masih setia dengan La Nggini. Setelah merasakan penderitaan yang dialami La Nggini melalui angin, La Nggusu memutuskan untuk pulang dari perantauannya. La Nggusu berharap dapat segera mengakhiri penderitaan yang dialami La Nggini dengan kepulangannya (Tuhan hadir). Namun di tengah perjalanan, kapal yang ditumpangi La Nggusu tenggelam di tengah lautan (Tuhan hadir). Akhirnya harapan La Nggusu tidak pernah menjadi kenyataan karena ia telah menjadi salah satu korban dalam tragedi tenggelamnya kapal.

La Nggini tetap dalam keadaan kesendirian dan penderitaannya. Ia berharap bahwa penderitaan yang alaminya segera berakhir. Ketika ia mendengar kabar kepulangan sang suami, La Nggini selalu menuruni bukit yang ia tinggali menuju dermaga. Ia berharap setiap kapal yang berlabuh itu adalah kapan yang

\footnotetext{
${ }^{1}$ Republik Indonesia, Undang-Undang Republik Indonesia Nomor 1 Tahun 1974 tentang Perkawinan, Bab 1, Pasal 1.
} 
mengantarkan kepulangan La Nggusu (Tuhan hadir). Tetapi harapan tersebut tidak pernah menjadi kenyataan. Akhirnya La Nggini tetap dalam penderitaannya sampai ia menjadi batu (Tuhan tidak hadir).

Ketiga peristiwa yang disebutkan di atas menurut Goldmann adalah peristiwa Tuhan tragis. Keberadaan Tuhan secara harfiah tidak menunjukkan eksistensinya sebagai penolong dalam penderitaan yang dialami manusia. Tetapi di sisi lain, manusia tetap berharap, namun manusia tetap kalah karena harapan tidak pernah menjadi kenyataan. Keadaan demikian disampaikan Lucaks - sebagaimana dikutip Goldmann-manusia berharap bahwa wahyu Tuhan akan menerangi berbagai perjuangan yang dia lihat di dunia sebelumnya, dan akan mengungkapkan kebenaran tertinggi. Tetapi dunia di sekelilingnya masih mengikuti jalan yang sama, acuh tak acuh terhadap pertanyaan dan jawaban. Tidak ada kata yang berasal dari hal-hal yang diciptakan atau hal-hal yang alamiah, dan rasnya bukan untuk cepat atau pertempuran untuk yang kuat. Suara jelas dari wahyu Tuhan tidak lagi terdengar di atas barisan takdir manusia, karena suara yang pernah menghidupkan semua orang kini telah diam. Manusia harus hidup sendiri dan sendirian. Suara sang Hakim telah diam selama-lamanya, dan inilah mengapa manusia akan selalu dikalahkan, ditakdirkan untuk kehancuran dalam kemenangan bahkan lebih dari pada kekalahan (Goldmann, 2003, hal. 35).

Manusia berharap bahwa wahyu Tuhan akan menyelamatkannya atas penderitaan yang dihadapi dan memberikan petunjuk yang benar. Tetapi dunia tidak peduli serta acuh tak acuh atas harapan, permohonan, serta kenyataan yang terjadi terhadap kehidupan manusia. Tidak ada mukjizat ataupun wahyu yang gamblang terjadi. Suara jelas dari Tuhan tidak pernah terdengar lagi hingga manusia harus sendiri. Tuhan telah selamanya diam dan manusia selalu ditakdirkan kalah dan hancur. Goldmann melanjutkan bahwa Tuhan bukan lagi pelindung manusia. Tuhan bukan lagi wali manusia dan pembimbingnya, bukan lagi orang yang bisa dia minta nasihat; ia telah menjadi aturan umum dan universal yang menjamin hak manusia untuk membebaskan dirinya dari otoritas eksternal apa pun, dan untuk mengikuti di mana kekuatan dan nalarnya dapat membimbingnya. Tetapi, pada saat yang sama, ia meninggalkan manusia sendirian di hadapan dunia yang diam dan statis dari hal-hal dan individu (Goldmann, 2003, hal. 38).

Tuhan bukan lagi wali dan pembimbing manusia, namun ia tetap hadir untuk memberi aturan dan batasan terhadap kehidupan manusia. Tuhan diam ketika tokoh La Nggini mengalami penderitaan. Tuhan pun masih diam ketika kapal yang ditumpangi La Nggusu di tengah perjalanan pulangnya. Tetapi Tuhan hadir ketika aturan membatasi La Nggini yang ingin bahagia. La Nggini bisa saja menikah dengan pria yang baru, namun aturan melarangnya. La Nggusu bisa saja menerima perjodohan yang ditujukan kepadanya, tetapi aturan dan rasa tanggung jawab atas sang istri membuatnya harus menolak. Semua aturan di atas adalah norma yang berlaku di masyarakat. Norma yang berlaku dianggap pamali, sakral serta mistis oleh masyarakat.

\section{Pandangan Mengenai Dunia}

Peristiwa pertama dalam legenda Wadu Ntanda Rahi yang menggambarkan pandangan dunia tragis adalah peristiwa ketika La Nggusu pergi merantau karena menginginkan penghasilan lebih tinggi dari daerah asalnya. Goldmann 
menyebutkan bahwa pandangan dunia tragis adalah kesadaran manusia akan dua ketidakcocokan yang terjadi. Namun, ketika keadaan kehidupan manusia di dunia sedang baik dan stabil antara harapan dan keinginan, manusia cenderung tidak mempermasalahkan problem yang dihadapi ketika keseimbangan ini (harapan dan kenyataan) dapat dibuat dengan mudah dan relatif stabil, atau ketika keseimbangan itu dapat dengan mudah berpindah dari satu bentuk ke bentuk lainnya, manusia cenderung tidak memikirkan masalah yang terjadi dalam hubungannya dengan dunia luar (Goldmann, 2003, hal. 48).

Hal demikian di atas berbeda dengan ketika manusia sedang mengalami krisis dan penderitaan di dunia. Manusia secara sadar mengetahui adanya ketidakcocokan di dunia. Manusia menolak keadaan tersebut, tetapi penolakan tersebut tidaklah menjauh dan pergi dari dunia itu sendiri. Pada bidang sosial maupun pada bidang individual, organ yang sakitlah (penderitaan) yang menciptakan kesadaran, dan pada masa-masa krisis sosial dan politik itulah manusia paling sadar akan teka-teki kehadiran mereka di dunia (Goldmann, 2003, hal. 48). Kesadaran tersebut diketahui manusia atas keterbatasan kekuatannya.

Peristiwa kedua adalah ketika La Nggusu sadar akan ketidakcocokan yang terjadi di dalam dunia. Ia berpikir bahwa setelah menikah kebutuhan hidup akan bertambah. La Nggusu memutuskan untuk meninggalkan daerah asalnya (penolakan terhadap dunia) untuk pergi merantau ke daerah yang memiliki penghasilan yang lebih tinggi (penolakannya tetap berada dalam dunia). La Nggini menolak penderitaan saat ia tinggal di kampung sehingga pergi ke bukit karena berharap mendapatkan ketenangan. Sama dengan peristiwa pertama di atas, keadaan dunia tragis yang kedua pun adalah kesadaran akan ketidakcocokan antara harapan dam kenyataan yang saling mengisi di dalam dunia. Setelah menikah, La Nggini mulai merasakan penderitaan karena ditinggal merantau oleh suaminya. Keadaannya yang tragis membuat ia memiliki pikiran tragis seperti yang dikatakan Goldmann (2003) bahwa dunia berada pada satu waktu dan sekaligus tidak ada apaapa dan segalanya. Dunia adalah satu-satunya tempat manusia mencoba kekuatannya. Kekuatan yang dimiliki manusia adalah ketabahan akan keadaan. Ketika La Nggini mengalami puncak penderitaannya, ia memutuskan untuk meninggalkan kampung (penolakan terhadap dunia) dan pergi tinggal di bukit (penolakannya tetap berada dalam dunia). La Nggini merasa kehidupan di kampung begitu gaduh, tetapi kehidupan di bukit adalah kehidupan yang tenteram. Ia memilih kehidupan di bukit karena ia merasa segala penderitaan bersumber dari masalah sosial yang terjadi di kampung. Kehidupannya di bukit dihabiskan dengan menyendiri sembari menunggu kepulangan san suami.

Kedua peristiwa dunia tragis di atas menggambarkan ketidakterimaan manusia atas ketidaksempurnaan dunia. Pikiran manusia yang tragis mengenali keterbatasan dunia, oleh karena itu menolaknya. Tetapi secara bersamaan, manusia menolak keterbatasan dunia sambil tetap berada di dalamnya. Menurut Goldmann, karena pikiran yang tragis tidak menyadari derajat atau bidang transisi antara tidak ada dan segalanya di dalam dunia, karena baginya segala sesuatu yang tidak sempurna itu tidak ada, karena ia tidak dapat melihat kemungkinan membawa ketidakhadiran dan kehadiran bersama, bahwa mata Tuhan membuat segala sesuatu yang tidak jelas dan tidak ambigu, dan yang tidak mencapai tingkat apa yang oleh Lukacs muda sebut 'keajaiban', sama sekali tidak ada dan tidak penting (Goldmann, 2003, hal. 49). 
Bagi pikiran manusia yang tragis, ketidakmungkinan di dalam dunia itu tidaklah ada, dan yang ada hanyalah kesempurnaan. La Nggusu menolak ketidaksempurnaan daerah asalnya. Menurutnya, daerah asalnya adalah daerah yang memiliki penghasilan rendah. Ia beranggapan bahwa di perantauan adalah daerah yang sempurnya sehingga kebutuhannya dengan sang istri akan terpenuhi. Begitu pun La Nggini, ia menolak keterbatasan kehidupan kampung yang kerap membuat ia menderita. Atas penderitaan yang dialaminya di kampung, La Nggini beranggapan bahwa kehidupan di bukit adalah kehidupan yang sempurna.

\section{Pandangan Mengenai Manusia}

Menurut Goldmann, ada dua karakteristik penting dari manusia tragis yang harus dicatat jika kita melihatnya sebagai realitas manusia yang koheren: pertama adalah bahwa ia membuat permintaan mutlak dan eksklusif untuk nilai-nilai yang mustahil; dan kedua adalah bahwa sebagai akibat dari itu, permintaannya adalah untuk 'semua atau tidak sama sekali', dan dia sama sekali tidak peduli dengan nilai dan perkiraan, dan konsep apa pun yang mengandung ide relativitas (Ramadhani et al., 2020).

Kedua tokoh utama dalam legenda Wadu Ntanda Rahi digambarkan sebagai manusia yang bernasib tragis. Tokoh suami meninggal dalam perjalanan pulang karena kapal yang ditumpanginya karam di tengah laut. Di sisi lain tokoh istri mengalami nasib tragisnya sendiri, yaitu dikisahkan sebagai manusia yang menjadi batu. Kedua nasib tragis dia atas menjelaskan keadaan manusia tragis menurut Goldmann. Manusia tragis menurut Goldmann (2003, hal. 63) adalah manusia yang menuntut secara mutlak atas nilai yang mustahil. Hal demikian tergambar pada tokoh La Nggini yang menjadi batu. Sebelum ia menjadi batu, La Nggini memohon agar cintanya diabadikan. La Nggini menginginkan kisah cintanya penuh kesetiaan dapat disaksikan oleh generasi yang akan datang. Permintaan La Nggini di atas merupakan tuntutan yang mustahil dapat terjadi menurut akal manusia. Selain mustahil, permintaan La Nggini tidak mengenali konsep relativitas. Ia hanya melakukan permintaan mutlak tanpa menyesuaikan dengan kemampuannya.

Goldmann (2003, hal. 81) melanjutkan manusia tragis itu sendirian, ditempatkan di antara dunia yang buta dan Tuhan yang tersembunyi serta diam. Tidak ada hubungan atau dialog antara manusia tragis, yang dapat diterima hanya sesuatu ambiguitas dan kontradiksi dunia. Hal demikian tergambar pada karakter tokoh suami. La Nggusu menginginkan untuk pergi merantau karena beranggapan bahwa daerah lain memiliki penghasilan lebih tinggi dari daerah tempat ia tinggal. Menurut La Nggusu, jika ia mendapatkan penghasilan yang lebih, kehidupan rumah tangganya akan lebih baik karena ekonomi tercukupi. Keinginan La Nggusu pada awalnya ditolak oleh anggota keluarga. Meski tidak digambarkan dalam cerita mengenai alasan penolakan tersebut, dapat diperkirakan alasan penolakan tersebut karena akan ada perpisahan antara kedua pasangan suami istri yang baru menikah, dan menurut keluarga penghasilan di daerah tempat mereka tinggal masih cukup untuk memenuhi kebutuhan sehari-hari. Jika dilihat dengan kondisi di masa sekarang, daerah Bima memiliki potensi pertanian yang cukup bagus (dapat dilihat pada bagian analisis tokoh La Nggusu). Berbagai hasil pertanian masih diekspor ke luar pulau. Meski keinginan La Nggusu pada awalnya ditolak, namun pada akhirnya keinginan tersebut disetujui oleh keluarga karena tekad dari La Nggusu yang kuat. 
Keadaan manusia tragis yang lain tergambar pada tokoh La Nggini ketika ia masih tinggal di bukit. Dalam proses wawancara dengan narasumber Alan Malingi, beliau menyebutkan bahwa masyarakat membujuk La Nggini supaya menuruni bukit dan tinggal di kampung layaknya kehidupan manusia seperti biasanya. Menurut Goldmann hubungan manusia tragis dengan manusia lain ada dua sisi dan paradoks. Di satu sisi, Ia berharap untuk menyelamatkan mereka untuk bersamanya. Di sisi lain, Ia sadar akan jurang besar yang memisahkannya dari mereka. Dengan demikian, Ia membiarkan mereka tetap seperti itu, karena bagaimanapun mereka adalah bagian dari alam semesta yang sekalipun ingin menghancurkan manusia, alam tidak akan tahu apa yang dilakukannya. Hubungan masyarakat dengan La Nggini adalah hubungan manusia tragis. La Nggini memutuskan tinggal di bukit karena ia malu telah difitnah telah berhubungan dengan pria lain ketika Ia jauh dengan suaminya. Di dalam masyarakat tradisional Bima, seseorang yang melakukan pelanggaran akan dihukum dengan diarak keliling kampung. Dengan demikian dapat dimaknai bahwa La Nggini telah diarak keliling kampung karena dianggap telah melanggar aturan. Atas tindakan hukuman tersebut, La Nggini memutuskan untuk meninggalkan kampung dan tinggal bukit. Setelah sekian lama dibujuk, La Nggini tetap kokoh pada pendiriannya, Ia masih tinggal di bukit sampai sang suami pulang dari perantauan. Akhirnya masyarakat pada saat itu membiarkan La Nggini dalam kesendiriannya. Setelah sekian lama tidak mendapat kabar tentang keadaan La Nggini, masyarakat beranggapan bahwa batu yang baru saja muncul dan berbentuk seperti manusia itu adalah La Nggini.

Menurut Goldmann (2003, hal. 83) manusia yang tragis tidak pernah dapat menerima keberadaan di dunia ini karena ia dapat menerima hal-hal yang tidak mudah rusak maupun nilai-nilai parsial yang tersirat dalam pemisahan jiwa dari tubuh. Hidupnya bermakna hanya sejauh sepenuhnya ditujukan untuk pencarian nilai total dan abadi, dan hanya ketika dia berusaha untuk mencapai ini bahwa jiwanya 'melampaui manusia' dan mencapai keabadian di dunia ini. Hal demikian tergambar pada tokoh La Nggini yang menjadi batu. La Nggini tidak menerima keadaan di dunia yang membuat perpisahan mereka. La Nggini menginginkan kisahnya diabadikan agar sampai kapan pun manusia lain dapat mengetahui cerita hidupnya.

Hubungan ketiga elemen tragis di atas hampir tidak didapatkan garis pemisahnya. Goldmann mengatakan bahwa masing-masing ketiga elemen tersebut tidak mengalami tragis dan paradoks jika tidak dikaitkan dengan elemen lainnya. Menurutnya tidak mungkin untuk membuat perbedaan yang jelas antara tiga elemen sebagai pembentukan visi Tuhan, dunia, dan manusia yang tragis, karena masingmasing dapat eksis dan didefinisikan hanya dengan merujuk pada dua lainnya (Goldmann, 2003, hal. 63).

Dalam cerita legenda Wadu Ntanda Rahi, tokoh La Nggini digambarkan sebagai tokoh yang mengalami krisis dalam hubungan sosial dan spiritual. La Nggini merasa malu karena telah difitnah dan di hukum oleh masyarakat. Krisis spiritual yang dialami oleh La Nggini, yaitu ketidakberperanan Tuhan dalam hidupnya yang penuh tragis dan secara bersamaan dunia tetap diam serta tidak tahu tentang nasib manusia sehingga La Nggini menyerah dan putus asa atas nasibnya. Hal demikian selaras dengan pendapat Goldmann yang menyatakan bahwa semua bentuk visi tragis memiliki satu ciri yang sama, yaitu mengekspresikan krisis mendalam dalam hubungan antara manusia dan dunia sosial dan spiritualnya. 


\section{PENUTUP}

Berdasarkan analisis pandangan dunia tragis pada legenda Wadu Ntanda Rahi milik Suku Bima maka dapat disimpulkan sebagai berikut. Dalam legenda Wadu Ntanda Rahi, dapat dilihat bahwa hubungan manusia dengan Tuhan dalam kenyataan terjadi tidak sesuai dengan apa yang diharapkan. Selain itu, ketidakberperanan Tuhan sebagai wasit atau hakim untuk mencegah ketidakadilan menguatkan prasangka ketiadaan-Nya. Di sisi lain, perilaku tokoh di dalam cerita tetap menunjukkan kepercayaannya terhadap Tuhan. Tokoh La Nggini tetap berharap kepada Tuhan agar ia bisa beranjak kehidupannya yang tragis. Harapan tersebut tidak pernah terkabul menjadi kenyataan, bahkan La Nggini di akhir cerita digambarkan sebagai seorang yang telah kehilangan segalanya. Sama halnya dengan La Nggini, La Nggusu pun mengalami nasib yang tragis. La Nggusu berharap di dalam perantaunya ia dapat membahagiakan La Nggini. Ia bekerja keras agar keluarganya yang baru terbentuk mendapatkan kehidupan yang lebih baik. Namun pada akhirnya, usahanya sia-sia dan La Nggusu meninggal dalam perjalanan pulang.

Keberadaan dunia yang diam dan bisu membuat kedua tokoh utama harus menolaknya. La Nggusu dan La Nggini menolak dunia yang terbatas dan jauh dari kata sempurna. Pada akhirnya, penolakan atas dunia tersebut tidak pernah meninggalkan dunia itu sendiri. Kedua tokoh utama menolak dunia sambil tetap berada di dalamnya. Hal demikianlah yang membuat kedua tokoh utama semakin terpuruk dalam nasib tragis. Manusia tragis memiliki keinginan yang mustahil dan tidak mengenal nilai-nilai relativitas. Keinginan La Nggini agar cintanya diabadikan terlampau sulit jika dinilai dengan penalaran manusia. Hal-hal yang bersifat abadi hanya dapat dilihat dari sudut pandang Sang Pencipta. Sedangkan hal-hal yang bersifat fana sangat tampak jika dilihat dari sudut pandang manusia.

Selain permintaan yang mutlak, manusia tragis ditakdirkan untuk tidak dipahami oleh manusia lain. La Nggusu ingin merantau karena ia beranggapan bahwa di daerah lain ia akan mendapatkan penghasilan lebih tinggi dari daerah asalnya. Pemikiran La Nggusu tersebut ditolak keluarga karena keluarga pun beranggapan daerah asalnya memiliki potensi yang cukup untuk memenuhi kebutuhan hidupnya. Alasan keluarga tersebut didukung dengan pergelaran kegiatan panen raya setiap tahunnya. Hal demikian menunjukkan bahwa hasil pertanian di daerah asalnya melimpah.

\section{DAFTAR PUSTAKA}

Anwar, A. (2012). Teori Sosiologi Sastra. Yogyakarta: Ombak.

Cohen, M. (1994). The Wager of Lucien Goldmann: Tragedy, Dialectics, and a Hidden God. New Jersey: Princeton University Press.

Danandjaja, J. (2007). Folklor Indonesia: Ilmu Gosip, Dongeng dan Lain-Lain. Jakarta: Pustaka Utama Grafiti.

Faruk. (2012). Pengantar Sosiologi Sastra dari Strukturalisme Genetik sampai Postmodernisme. Yogyakarta: Pustaka Pelajar.

Frederico, C. (2012). Who speaks in cultural creation? Notes on Lucien Goldmann. Matrizes, 5(2), 181-194. https://doi.org/10.11606/issn.1982-8160.v5i2p181194

Goldmann, L. (1977). Cultural Creation in Modern Society. Oxford: Basil Blackwell. 
Goldmann, L. (1980). Essays on Method in the Sociology of Literature. St. Louis, Missouri: Telos Press.

Goldmann, L. (2013). The Hidden God: A Study of Tragic Vision in the Pensées of Pascal and the Tragedies of Racine. New York: Routledge.

Hasanah, H., \& Sukmawan, S. (2021). Berbingkai Kemajemukan Budaya, Bersukma Desakalapatra: Selidik Etnografi atas Tradisi Tengger. Diglosia: Jurnal Kajian Bahasa, Sastra, dan Pengajarannya, 4(1), 79-90. https://doi.org/10.30872/diglosia.v4i1.102

Hasanah, U. (2018). Nilai-Nilai Moral dalam Novel Wadu Ntanda Rahi Karya Alan Malingi. Universitas Muhammadiyah Malang. Diambil dari http://eprints.umm.ac.id/37530/

Miles, M. B., Huberman, A. M., \& Saldana, J. (2018). Qualitative data analysis: A methods sourcebook (4th ed.). California: SAGE Publications.

Nurlaila. (2018). Adat Perkawinan Masyarakat Bima (Mbojo) dalam Novel "Wadu Ntanda Rahi" Karya Alan Malingi (Kajian Mimetik). Universitas Muhammadiyah Makassar. Diambil dari https://digilibadmin.unismuh.ac.id/upload/3096Full_Text.pdf

Ramadhani, Rokhmansyah, A., \& Dahlan, D. (2020). Pandangan Dunia Tragis dalam Novel Pacarku Wanita Kuyang Karya Dewi Nina Kirana. Madah, 11(1), 97-112. https://doi.org/10.31503/madah.v11i1.244

Sudikan, S. Y. (2001). Metode Penelitian Kebudayaan. Surabaya: Citra Wacana. 
A. Wibowo, A. Rokhmansyah, \& D. Dahlan 